\title{
Heat and Mass Transfer Processes in Scrubber of Flue Gas Heat Recovery Device
}

\author{
Ivars Veidenbergs, Institute of Energy Systems and Enviroment, Riga Technical University, Dagnija Blumberga, \\ Institute of Energy Systems and Enviroment, Riga Technical University, Edgars Vigants, SIA "Ludzas Bio-Energija”, \\ Grigorijs Kozuhars, Institute of Energy Systems and Enviroment, Riga Technical University
}

\begin{abstract}
The paper deals with the heat and mass transfer process research in a flue gas heat recovery device, where complicated cooling, evaporation and condensation processes are taking place simultaneously. The analogy between heat and mass transfer is used during the process of analysis. In order to prepare a detailed process analysis based on heat and mass process descriptive equations, as well as the correlation for wet gas parameter calculation, software in the Microsoft Office Excel environment is being developed.
\end{abstract}

Keywords - flue gas deep cooling, heat mass transfer, heat recovery device.

\section{I.INTRODUCTION}

Little by little energy wood utilization in Latvian boiler houses has become the main activity for replacing fossil fuels and reducing the impact on climate change. Latvia has a high energy wood potential and an opportunity to fulfil, to a large extent, the demand for heat energy consumption in the country with renewable energy resources.

Energy wood is used at a low level of efficiency, which is often only $60 \ldots 70 \%$. This is due to both the high fuel moisture, the inferior organisation of the combustion process, and the fact that the flue gas is not completely cooled - flue gas is extracted from the boiler while at a high temperature.

A flue gas deep cooling heat recovery device is developed to increase the boiler house efficiency. The flue gas is not only cooled in the heat recovery device, but there is also a condensed vapour from the flue gas [1]. Vapour in the flue gas forms mainly from the fuel moisture, which does not participate in the burning process, but only uses heat for the moisture evaporation process. The higher the moisture content, the lower the amount of efficient heat produced by the boiler house and transferred to heat consumers.

The heat recovery device for flue gas cooling is strategically important for the Latvian energy industry, as, by burning energy wood with a high moisture content, the efficiency of boiler houses could be increased by $5-10 \%$, which would make it possible to increase the proportion of renewable energy in the energy sector, owing to the fact that energy wood is used more rationally.

The paper deals with the process research of the heat and mass transfer in the flue gas heat recovery device, where complicated cooling, evaporation and condensation processes are taking place at the same time with the partition of hard particles and absorption of various gaseous components.

\section{II.HEAT RECOVERY DEVICE DESCRIPTION}

Outflow gas heat recovery is accomplished by direct contact between flue gas and spraying water in the heat recovery device. Flue gas is cooled below the dew point and in this case, both physical gas heat and condensing the vapour phasetransition heat is used $[2,3]$. Heat recovery activity is related to the heat and mass transfer, which takes place between the flue gas and spraying water. Condensate pellicle, which forms on the heat transfer surface, creates the sedimentation of hard particle from flow and absorption of gaseous components. Heat and mass transfer intensification is associated with a more powerful vapour-gas flow cooling and contributes to an increase in the gas depuration efficiency. The principle scheme of heat recovery is shown in Figure 1.

The heat recovery device consists of two parts:

- scrubber without packing (3);

- scrubber with packing (6).

Each part has to perform its specific functions. In the first part flue gas, which is taken into the device beyond the boiler, is cooled to a temperature, which is permissible for the longterm operation of the second part with packing. This part should also increase the moisture content of the flue gas to raise the vapour condensation in the second part. For gas cooling, as well as for increasing moisture content, water from the bottom of the heat recovery device is sprayed into the gas through the nozzles 2 . The water temperature is above the dew point temperature, and may achieve the wet bulb temperature. Due to the water temperature and low amount of water, compared with the spraying in the scrubber with packing, water evaporation takes place in the first part along the scrubber without packing. The water temperature at the outlet of the first part is equal, or close to the wet-bulb temperature. The hard particles which remain in the flue gas after cyclone are also processed in the first part and, with water, drained into the water part of the device. Spraying water and gas coflow takes place in the first part of the device.

The moistened and pre-cooled flue gas enters the second part of the scrubber with packing. Gas moves into the device from bottom to top through packing 6 , and oncoming from the top spraying water flows making co-flow. The task of the second part is to establish deep flue gas cooling and vapour condensation. Therefore, it is preferable to have water with as low temperature as possible sprayed through nozzles 5. Water for spraying is taken from the water tank of the device and fed into the nozzles through the network heat exchanger 5 . 


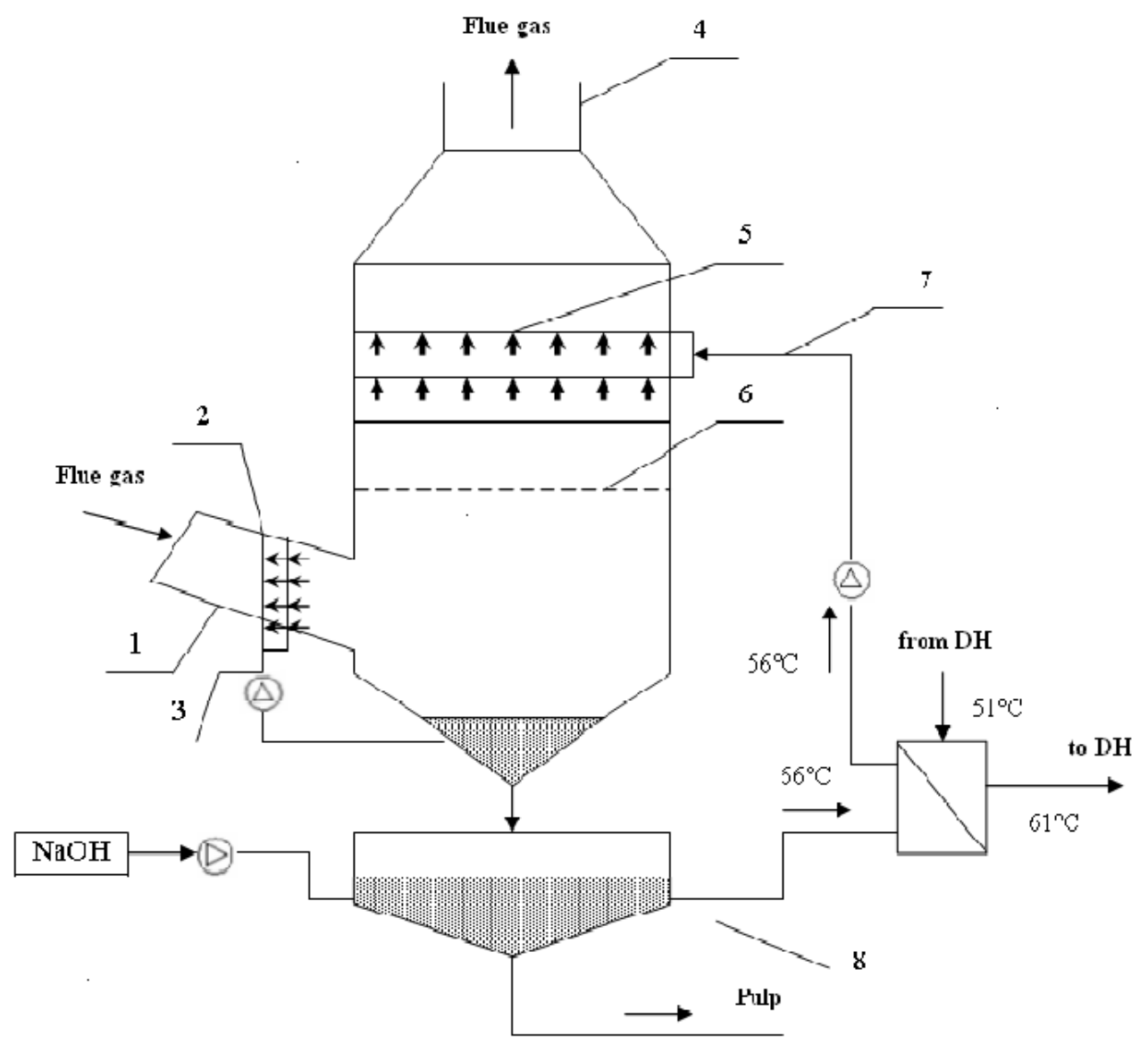

Fig. 1. Heat recovery device and its connection principal scheme: 1 - scrubber without packing; 2.5 - spray nozzles, 3.7 - water supply to the nozzles 4 - chimney, 6 - scrubber packing, 8 - water supply to heat exchanger of district heating network.

The water temperature is determined by transferred heat in the heat exchanger. The transferred heat amount depends on the return temperature in the network. The useful heat of the device is heat transferred to the network water into the heat exchanger. Useful heat is obtained in the second part of the device - scrubber with packing. The quantity of spraying water is significantly greater through the nozzles 5 compared to nozzles 2. To remove the collected hard particles and protect the heat exchanger surface from the cooling, a settling tank is used. Due to the formation of condensation, the water level in the reservoir rises and part of the water is removed together with hard particles as pulp. Condensation makes the environment acidic and thus $\mathrm{NaOH}$ is used for its neutralization. The acidic environment is formed by liquescent oxides of condensate contained in flue gas.

Teller sockets are used as packing 6 of the heat recovery device. Sockets have a large surface area, low aerodynamic resistance and can be used in an environment with temperatures of around $100^{\circ} \mathrm{C}$ and higher $\left(130^{\circ} \mathrm{C}\right)$. Another packing is located over the nozzles 5 before the gas output to the chimney. The task of this packing is to dry the flue gas and remove water drops.
Overall, the heat recovery device is designed to separate the first evaporative part from the second condensing parts. In this way, favourable conditions are secured for each process. The target for further research is the identification of these conditions.

\section{CALCULATION AND ANALYSIS OF HEAT AND MASS TRANSFER PROCESS IN THE EVAPORATION PART (SCRUBBER WITHOUT PACKING) OF THE HEAT RECOVERY DEVICE}

The task of the evaporation part is to cool the flue gases till a definite temperature, which is terminated by packing material permissible temperature, as well as to increase the moisture content of the gas. Water drops sprayed into the scrubber and the hot flue gas creates co-flow. To ensure water evaporation, the spraying water temperature should be above the gas dew point temperature $t_{\bar{u}}>t_{r}$. Wet gas cooling will occur, if the gas temperature is $t_{g}>t_{\bar{u}}$. The flue gas cooling takes place by heating up the spraying water in the scrubber. In this way, heat and mass transfer occurs between the water and wet flue gas and these processes can have both the same direction and also be contrary to one other. The process mechanism and driving forces are shown in Figure 2. 


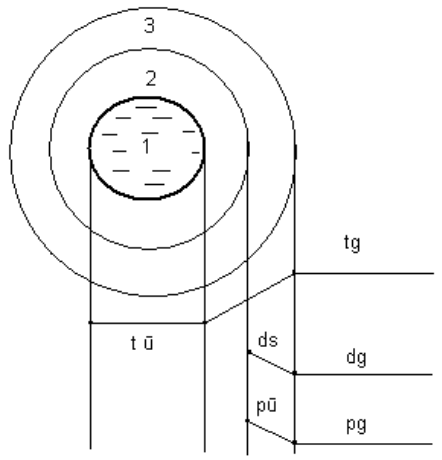

Fig. 2. Heat and mass transfer process parameter changes for the evaporation part of the heat recovery device.

Transfer processes do not occur directly between the gas and water drops, but through the boundary layers. The water evaporates from the water drop of surface 1. Around this drop gas saturated boundary layer is formed 2, where the vapour is in a saturation position. In this layer, vapour partial pressure corresponds to the saturation pressure and its value is determined by the drop temperature, which varies from $t_{\bar{u}}$ at the spraying place to the wet-bulb temperature $t_{m}$ in the device outlet. An unsaturated gas boundary layer forms between the gas flow nuclei and the saturated gas boundary layer 3 in which the dry-bulb gas temperature changes take place. The gas temperature changes from $t_{g}$ in the flow centre to the gas saturation temperature at the outer surface of the saturated gas boundary layer. The unsaturated gas boundary layer 3 covers the saturated gas boundary layer 2 .

The heat and mass transfer in the heat recovery device is a complex process, where dry heat transfer and mass transfer occur simultaneously [4]. The dry heat transfer is driven by the temperature difference between the heat carriers - the flue gas and the spraying water. As the flue gas temperature $t_{g}$ is higher than the water temperature $t_{\bar{u}}$, then the energy is transferred from the flue gas to the water, and as a result the water gets warmer, but the flue gas cools. Heat transfer occurs simultaneously with mass transfer, which is determined by its own drivers. As mass transfer driving force may be used the water vapour partial pressure in the saturated gas boundary layer $p_{\bar{u}}$ and vapour partial pressure $p_{g}$ difference in gas or saturation position of moisture content $d_{s}$ and gas moisture content $d_{g}$ difference. The mass transfer process direction may or may not coincide with the heat transfer. It depends on water temperature. If the water temperature is lower than the wet gas dew point temperature $t_{r}$, the mass and the heat transfer is directed from gas to water. Water vapour condensation on the drop surface will take place and gas moisture content will decrease. If the water temperature is higher than the gas dew point temperature, then water will evaporate and the gas moisture content will increase. In this case, mass transfer and heat transfer are orientated against each other.

The wet gas condition can be determined by different parameters set, including the gas dry-bulb temperature $t_{g}$ and moisture content $d_{g}$. Both parameters are included in the gas enthalpy, which is used for heat and mass exchange calculations.

The spraying water introduced into the heat recovery device can be heated up to a certain limit, which corresponds to the gas wet bulb temperature. Reaching the wet-bulb temperature the water is not heated up any more and all supplied heat is consumed for water evaporation. Thus, a thermodynamic balance occurs between the flue gas and spraying water, which can be described by the equation.

$$
\alpha_{k} \cdot\left(t_{g}-t_{m}\right) \cdot d F=r \cdot \beta \cdot\left(d_{m}-d_{g}\right) \cdot d F,
$$

where

$\alpha_{\mathrm{k}} \quad$ - convective heat return ratio from gas to water, $\mathrm{kW} /\left(\mathrm{m}_{2} \cdot \mathrm{K}\right)$;

$\mathrm{t}_{\mathrm{g}} \quad$ - flue gas temperature, ${ }^{0} \mathrm{C}$;

$\mathrm{t}_{\mathrm{m}} \quad$ - wet-bulb temperature, ${ }^{0} \mathrm{C}$;

$\mathrm{dF}$ - elemental contact surface between gas and water, $\mathrm{m}^{2}$;

$\mathrm{r} \quad$ - water vaporization heat, $\mathrm{kJ} / \mathrm{kg}$;

$\beta \quad$ - mass transfer ratio, $\mathrm{kg} /\left(\mathrm{m}^{2} . \mathrm{s}\right)$;

$\mathrm{d}_{\mathrm{m}} \quad$ - saturated gas moisture content corresponding to water temperature $\mathrm{t}_{\mathrm{m}}, \mathrm{kg} / \mathrm{kg}$ dry gas;

$\mathrm{d}_{\mathrm{g}} \quad$ - unsaturated gas moisture content, $\mathrm{kg} / \mathrm{kg}$ dry gas.

The analysis, conducted on the basis of the similarity theory, shows that an analogy between heat and mass transfer is observed in the evaporation processes. This means that the heat and mass transfer ratio should have a relationship. This correlation is known as the Luisa figure and determines that the heat output coefficient of the ratio of mass transfer coefficient is equal to the mass of the gas specific heat capacity

$$
\frac{\alpha_{k}}{\beta}=c_{p g}
$$

Subject to the relationship (1) and (2), the wet-bulb temperature can be defined as

$$
t_{m}=t_{g}-\left(\frac{r}{c_{p g}}\left(d_{m}-d_{g}\right)\right)
$$

The expression (3) shows that the wet-bulb temperature is determined by:

- gas temperature;

- $\quad$ saturated gas moisture content above the water film or drop;

- $\quad$ input gas moisture content in device.

If the gas cools reaching the position where its moisture content becomes equal to the gas saturation position of the moisture content $d_{g}=d_{m}$, the wet and dry bulb temperature becomes equal. Expression (3) shows that the temperature difference between the dry and wet-bulb temperature increases by reducing the gas moisture content. The wet-bulb 
temperature changes depending on the gas temperature and moisture content shown in Figure 3.

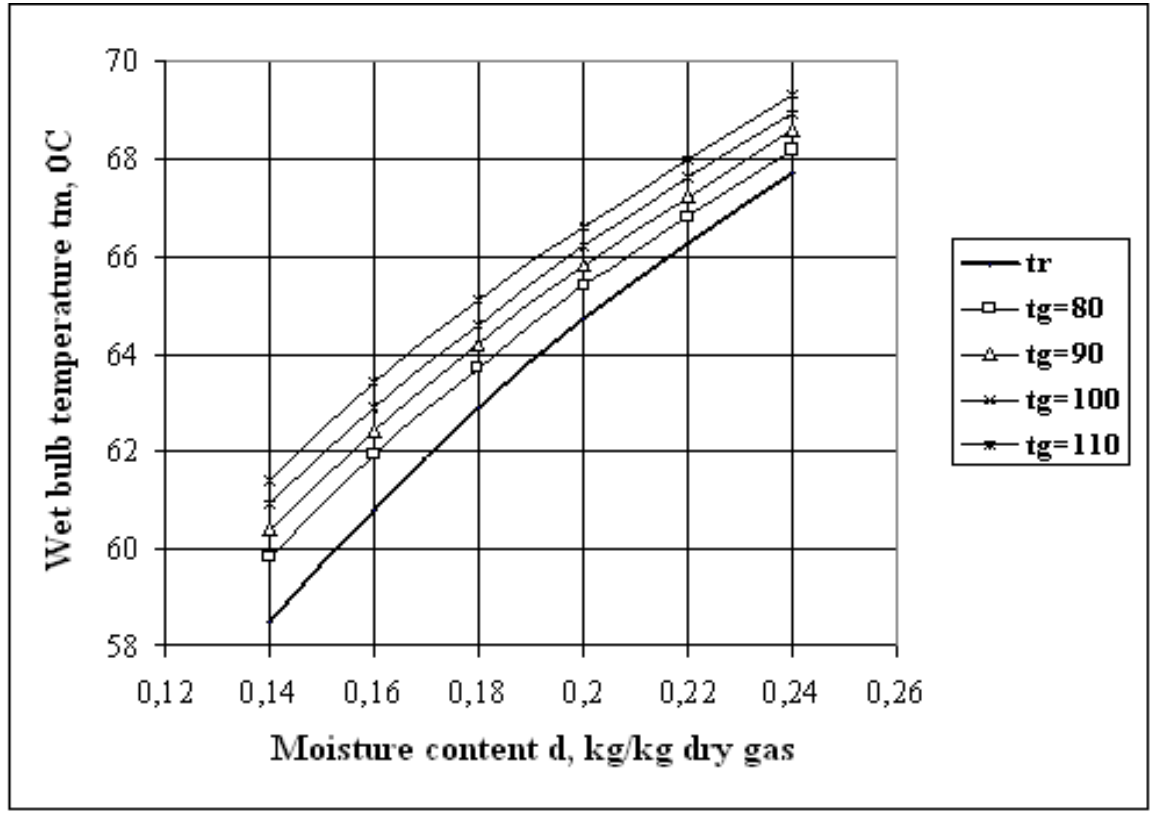

Fig. 3. Wet-bulb temperature changes depending on the gas temperature and moisture content.

Wet-bulb temperature changes in nature suggest that temperature increases with increasing gas moisture content. This means that, at the same gas temperature, in the case of higher flue gas moisture the spraying water can be heated to higher temperatures. The figure 3 shows the dew point temperature changes in the changing gas moisture content. Dew point temperature values at similar levels of gas moisture content are lower than the wet-bulb temperature.

The heat and mass transfer process parameter changes, for gases flowing through the contact of the device can be shown graphically. For that purpose a $t$ - $d$ graph (shown in Figure 4) is used. The gas moisture content changes subjected to a dry gas mass unit are on the horizontal-axis. The vertical axis shows gas dry-bulb values. Points a - b are located on the gas saturation curve, where the relative humidity is $100 \%$. Gas parameters of the heat recovery device input are characterised by position A.

After inlet into the scrubber, the wet gas actually comes into contact with the saturated vapour layers (not with water mass), which are located above the water surface (layer 2 in Figure 2). This means that the contact takes place between two different parameter gases. The results of the various gas mixing process parameters in the $h-d$ diagram are shown on the straight line which joins the points characterising gas conditions.

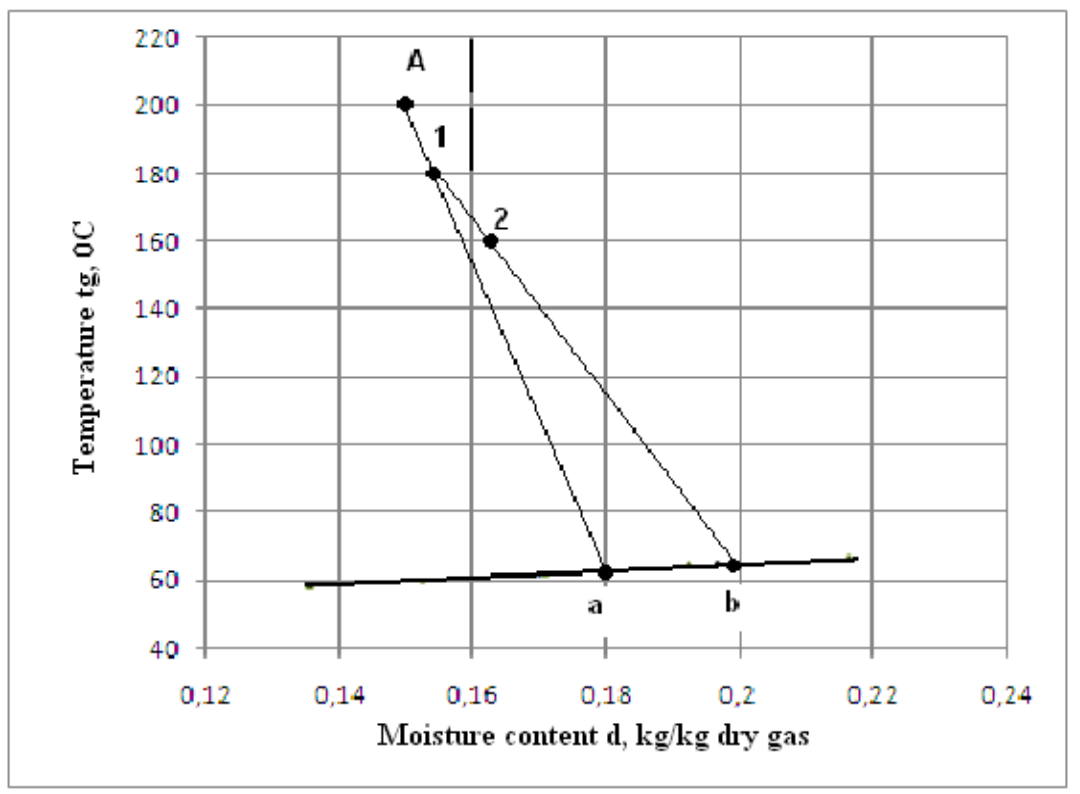

Fig. 4. Scrubber processes $t$ - $d$ chart. 
To determine all the typical parameters at the outlet of the scrubber, it is necessary to perform a calculation of the ongoing process. Knowing the gas temperature in the scrubber lead-in $t_{g A}$ and assuming the gas temperature at the outlet $t_{g B}$, scrubber is divided into elementary stages $\left(t_{g A}-t_{g B}\right) / n$ with a fixed gas temperature at the end phase $t_{g l}, t_{g 2}$, etc. The first and the second phases are characterised by the end conditions of points 1 and 2, respectively in the $t-d$ diagram in Figure 4. It should be pointed out that, in the frameworks of elementary stages, there are the same flue gas temperature changes and their geometric dimensions can be different. Data on the heat and mass transfer ratio or spraying water drops evaporation process are required for transfer to the geometric dimensions [5].

If the spraying water temperature is higher than the corresponding position of the gas dew point temperature and below the wet-bulb temperature $t_{\bar{u}}>t_{r}>t_{m}$, then the water will evaporate and the gas moisture content will increase. The moisture content after the first stage (point 1) is

$$
d_{l}=d_{A}+\Delta d_{l}, \mathrm{~kg} / \mathrm{kg} \text { dry gas, }
$$

where

$\Delta \mathrm{d}_{1} \quad$ - moisture content increase in the result of water evaporation, $\mathrm{kg} / \mathrm{kg}$ dry gas

The moisture content increase $\Delta \mathrm{d}_{1}$ is defined by the input gas moisture content $\mathrm{d}_{\mathrm{A}}$ and corresponding to the spraying water temperature saturation position water content $d_{a}(a$ condition in Figure 3).

The moisture content after the second phase can be calculated similar to expression (4)

$$
d_{2}=d_{1}+\Delta d_{2}, \mathrm{~kg} / \mathrm{kg} \text { dry gas. }
$$

Here the moisture content increase $\Delta \mathrm{d}_{2}$ is determined by the moisture content $d_{1}$ and the first phase of the corresponding water temperature $t_{\bar{u} 1}$ saturation position of the moisture content $d_{b}$ (position $\mathrm{b}$ in Figure 4). Since spraying water evaporates, then the quantity is decreasing. The amount of water at the end of the first stage can be calculated as

$$
G_{\bar{u} l}=G_{\bar{u} A}-L_{s . g .}\left(d_{A}-d_{l}\right), \mathrm{kg} / \mathrm{s} \text {, }
$$

where

$\mathrm{L}_{\text {s.g. }} \quad$ - quantity of the dry gas in the scrubber, kg dry gas/s.

Gas enthalpy per $\mathrm{kg}$ is determined by the expression

$$
h=c_{p s . g .} . t_{g}+d .\left(2500+1,97 . t_{g}\right), \mathrm{kJ} / \mathrm{kg} \text { dry gas. }
$$

where

c ps.g. - dry gas specific heat capacity, $\mathrm{kJ} /(\mathrm{kg}$ dry gas $\mathrm{K})$.
Flue gas comes in contact with the spraying water in the scrubber, transferring heat back to the water and as a result -cools. In turn, by collecting the heat from the flue gas the water partially evaporates and the gas moisture content increases. Water temperature changes in the elementary stages of the scrubber can be determined by the heat and mass balance equation.

The heat balance equation for elementary stages links the stage input and output heat

$$
d Q_{g}^{\prime}+d Q_{\bar{u}}^{\prime}=d Q^{\prime}{ }_{g}+d Q^{\prime}{ }_{\bar{u}},
$$

where

dQ' ${ }_{g}, d Q{ }_{g}$ - gas heat input and output in the scrubber element; $\mathrm{dQ}_{\overline{\mathrm{u}}}, \mathrm{dQ}{ }_{\overline{\mathrm{u}}}$ - water heat input and output in the scrubber element.

By defining the elements $f$ the heat balance equation for elementary stage (8) heat balance could be expressed as

$$
\begin{gathered}
L_{s . g} \cdot\left(c_{p s . g . A} \cdot t_{g A}+d_{A \cdot} \cdot\left(2500+1,97 \cdot t_{g A}\right)+G_{\bar{u} A \cdot} \cdot c_{p \bar{u}} \cdot t_{\bar{u} A}=\right. \\
=L_{s . g \cdot}\left(c_{p s \cdot g . l} \cdot t_{g l}+d_{A} \cdot\left(2500+1,97 \cdot t_{g l}\right)+\right. \\
+\left(G_{\bar{u} A}-L_{s . g .} \cdot\left(d_{A}-d_{1}\right)\right) \cdot c_{p \bar{u}} \cdot t_{\bar{u} l}
\end{gathered}
$$

Expression calculation for water temperatures determined at the outlet of the elemental phase can be achieved from the heat balance equation. Considering the interconnection (6) (7) and (9) that is

$$
t_{u 1}=\frac{L_{s . g} \cdot\left(h_{A}-h_{1}\right)+G_{\bar{u} A} \cdot c_{p \bar{u}} \cdot t_{\bar{u} A}}{\left(G_{\bar{u} A}-L_{s . g} \cdot\left(d_{A}-d_{1}\right)\right) \cdot c_{p \bar{u}} \cdot t_{\bar{u} 1}}
$$

If there are some known parameters of the scrubber elementary stage outlet at the position 1 , then the same can be calculated for the system parameters at the position 2 and then to the entire scrubber. The water and flue gas parameters at the scrubber outlet are determined by calculation. Scrubber output parameters are heat recovery device input data in the second part (scrubber with a packing). By using the calculated data between the positions, it is possible to show processes in the scrubber. The process procedure is shown in Figure 5.

Two processes are compared in the figure 5 . The processes differ by the spraying water amount in the scrubber. Flue gases with the same parameters are infused into both processes (position A). In the process described in curve 1 , the spraying water amount is less than in process 2 and shows that, at the gas end position (point $\mathrm{B}_{1}$ ), the moisture content is higher. The processes closing position $\mathrm{B}$ parameters are initial parameters for the heat recovery device the second part - in scrubber with a packing. 


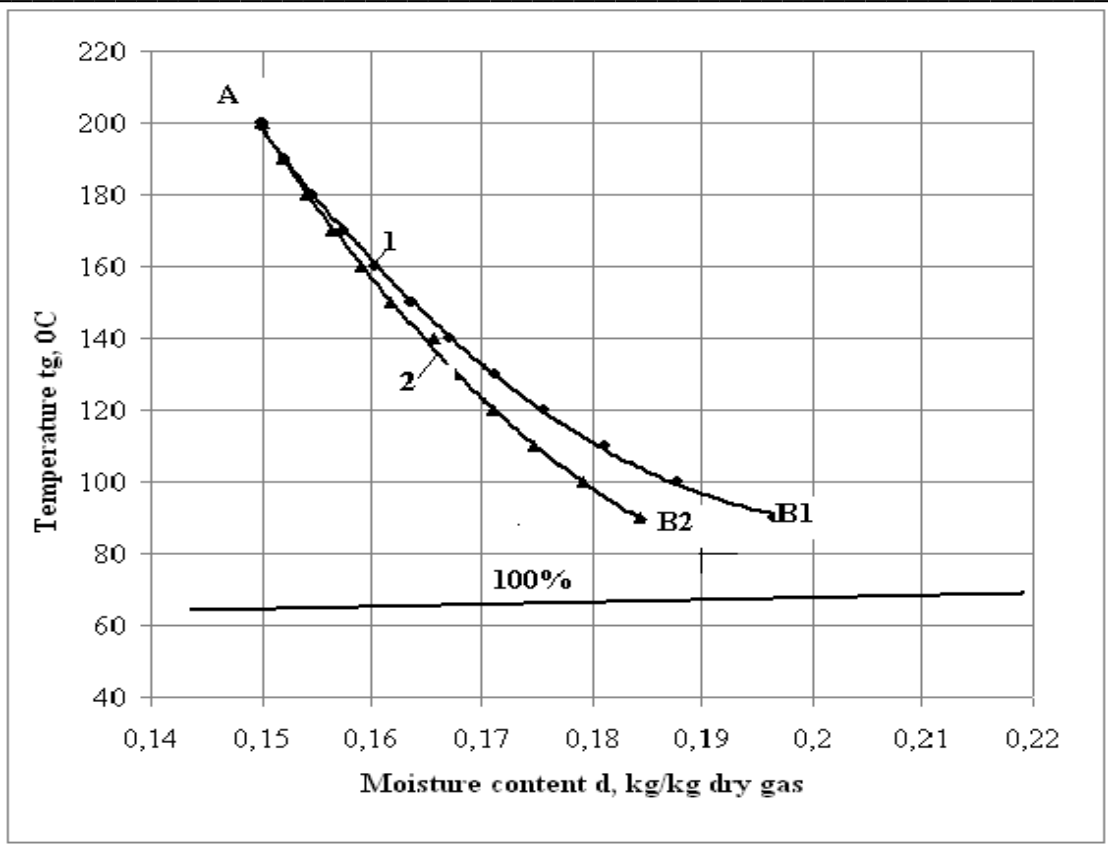

Fig. 5. Gas temperature and moisture content changes in scrubber.

\section{CONCLUSIONS}

A wet flue gas heat utilization system is build up from two parts - an empty scrubber and a scrubber with packing. The paper deals with heat and mass transfer processes in the scrubber part.

The action of the scrubber is of two sorts:

- cool down gas up to a certain temperature which is determined by the permissible temperature of the packing material;

- $\quad$ increase gas moisture content as much as possible.

Spraying water drops and hot flue gas create co-flow in the scrubber. To ensure the water evaporation spraying, the water temperature must be above the gas dew point temperature $\mathrm{t}_{\overline{\mathrm{u}}}>\mathrm{t}_{\mathrm{r}}$.

Transfer processes are not taking place directly between the gas and water drops, but through the boundary layer. When water evaporates from the water drop surface, a gas saturated boundary layer is formed around the drop. The vapour in the boundary layer is in the saturation position. In this layer the partial pressure of vapour corresponds to the saturation pressure and its value is determined by the drop temperature which changes from the spraying site to the wet-bulb temperature of the scrubber outlet. While reaching the wetbulb temperature, the water does not heat any more and all the supplied heat is consumed for water evaporation. A thermodynamic balance occurs between flue gas and spraying water.

Descriptive equations and graphically displayed progress of the process are provided in the paper. The analogy between heat and mass transfer is used in the process of analysis. Based on the heat and mass process descriptive equations, as well as on the correlation for wet gas parameter calculation, software in the Microsoft Office Excel environment is being developed for a detailed process analysis and optimization.

\section{REFERENCES}

1. Blumberga D., Vigants E., Veidenbergs I., Rochas C., Selivanovs J., Lapiņs L., Liepins I. Gāzes kondensators. - Patents Nr. 14116, 2010.

2. Cortina M. Flue gas condenser for biomass boilers. Master's Thesis. Lulea University of Technology, Division of Energy Engineering, 2006.$77 \mathrm{p}$.

3. Defu C., Yanxua L., Chunyang G. Evaluation of retrofitting a conventional natural gas fired boiler into a condensing boiler. Energy Convertion and Management 45, 2004. - 3251-3266p.

4. Нефедова Н.И. Моделирование прочессов тепло- и массообмена при утилизачии высоковлажных тепловых вторичных энергоресурсов. - Москва: Московский Энергетический Институт, Дис.канд.техн.наук. 2006. - 139 с.

5. Valdberg A.Y., Zhigun O.V. Designing hollow spray scrubbers for evaporative gas cooling. J. Chemical and Petroleum Engineering, Vol. 44., 2008. - 67-72 p.

Ivars Veidenbergs, Dr.hab.sc.ing., Professor

Riga Technical University, Institute of Energy Systems and Environment Address: Kronvalda 1, LV1010, Riga, Latvia

Phone: +37167089901

e-mail: ivars.veidenbergs@ @rtu.lv

Dagnija Blumberga, Dr.hab.sc.ing., Professor

Riga Technical University, Institute of Energy Systems and Environment Address: Kronvalda 1, LV1010, Riga, Latvia

Phone: +37167089901

e-mail: dagnija.blumberga@rtu.lv

Edgars Vigants, M.sc.ing., Member of the board SIA "Ludzas Bio-Energija"

Address: S. Eizensteina 29, LV1079, Riga, Latvia

Phone: +37167817090 , Fax: +37167817087

e-mail: edgars.vigants@balteneko.lv

\section{Grigorijs Kozuhars, M.sc.ing.}

Riga Technical University, Institute of Energy Systems and Environment

Address: Kronvalda 1, LV1010, Riga, Latvia

Phone: 37167089908

e-mail: grigorijsk@inbox.lv 
Ivars Veidenbergs, Dagnija Blumberga, Edgars Vīgants, Grigorijs Kožuhars. Siltuma un masas apmaiṇas procesi dūmgāzu dziḷas dzesēšanas tieša kontakta aparāta skrubera dạ̄ā

Kontakta aparātā dūmgāzu un iesmidzināmā ūdens tieša kontakta ceḷā tiek realizēta aizplūstošo gāzu siltuma utilizācija, dzesējot tās zem rasas punkta un šajā gadījumā izmantojot gan gāzu fizisko siltumu, gan kondensējošos tvaiku fāzu pārejas siltumu. To darbība ir saistīta ar siltuma un masas pāreju, kura notiek starp dūmgāzēm un iesmidzināto ūdeni. Apmaiņas procesi nenotiek tieši starp gāzēm un ūdens pilieniem, bet gan caur robežslāņiem. Ūdenim iztvaikojot no ūdens piliena virsmas, ap pilienu veidojas piesātināts gāzu robežslānis, kurā tvaiks atrodas piesātinājuma stāvoklī. Šajā slānī tvaika parciālais spiediens atbilst piesātinājuma spiedienam un tā vērtību nosaka piliena temperatūra, kura mainās no ūdens temperatūras iesmidzināšanas vietā līdz mitrā termometra temperatūrai skrubera izejā. Sasniedzot mitrā termometra temperatūru, ūdens vairāk neuzsilst un viss pievadītais siltums tiek patērēts ūdens iztvaikošanai. Starp dūmgāzēm un iesmidzināmo ūdeni iestājas termodinamisks līdzsvars. Darbā sniegti procesus aprakstoši vienādojumi un paradīta grafiski procesu norise. Procesu analīzē izmantota analoǵija starp siltuma un masas pārnesi. Balstoties uz siltuma un masas procesus aprakstošiem vienādojumiem, kā arī sakarībām mitru gāzu parametru aprēķinam, detalizētai procesu analīzei un optimizācijai tiek izmantota Microsoft Office Excel vidē izveidota datorprogramma.

Иварс Вейденбергс, Дагния Блумберга, Эдгарс Вигантс, Григорыс Кожухарс. Процессы тепло- и массообмена в контактном аппарате глубокого охлаждения дымовых газов

В результате непосредственного контакта дымовых газов и впрыскиваемой воды в контактном аппарате реализуется утилизации тепла исходящих газов, охлаждая их ниже точки росы, и в этом случае, используя как физическое тепло газов, так и переходное тепло фаз конденсирующихся паров. Процесс связан с тепло- и массообменом, который проходит между дымовыми газами и впрыскиваемой водой. Процессы обмена не происходят непосредственно между газом и каплями воды, а через разграничивающие слои. Вода, испаряясь с поверхности капли воды, образует вокруг капель газонасыщенный разграничивающий слой, в котором пар находится в состоянии насыщения. В этом слое парциальное давление пара соответствует давлению насыщения, и его значение определяет температура капли, которая меняется от температуры воды в месте впрыскивания до температуры по мокрому термометру на выходе из скруббера. Достигнув температуры по мокрому термометру, вода больше не нагревается, и всё подведенное тепло расходуется на испарение воды. Между дымовыми газами и впрыскиваемой водой устанавливается термодинамическое равновесие. В работе даны уравнения описывающие процессы и графически показан ход процессов. В анализе процессов использована аналогия между тепло- и массообменом. Основываясь на уравнениях описывающих процессы тепло и массообмена, а также на расчётах зависимости параметров влажных дымовых газов, для детального анализа и оптимизации процессов разработана компьютерная программа в среде Microsoft Office Excel. 